\title{
Nematicidal activity of fervenulin isolated from a nematicidal actinomycete, Streptomyces sp. CMU-MH021, on Meloidogyne incognita
}

\author{
Pornthip Ruanpanun • Hartmut Laatsch • \\ Nuchanart Tangchitsomkid · Saisamorn Lumyong
}

Received: 1 July 2010/Accepted: 20 September 2010/Published online: 22 October 2010

(C) Springer Science+Business Media B.V. 2010

\begin{abstract}
An isolate of the actinomycete, Streptomyces sp. CMU-MH021 produced secondary metabolites that inhibited egg hatch and increased juvenile mortality of the root-knot nematode Meloidogyne incognita in vitro. $16 \mathrm{~S}$ rDNA gene sequencing showed that the isolate sequence was $99 \%$ identical to Streptomyces roseoverticillatus. The culture filtrates form different culture media were tested for nematocidal activity. The maximal activity against M. incognita was obtained by using modified basal (MB) medium. The nematicidal assay-directed fractionation of the culture broth delivered fervenulin (1) and isocoumarin (2). Fervenulin, a low molecular weight compound, shows a broad range of biological activities. However, nematicidal activity of fervenulin was not previously reported. The nematicidal activity of fervenulin (1) was assessed using the broth microdilution technique. The lowest minimum inhibitory concentrations (MICs) of the compound
\end{abstract}

\section{P. Ruanpanun}

Biotechnology Program, Graduate School, Chiang Mai

University, Chiang Mai 50200, Thailand

e-mail: pornthip374@hotmail.com

\section{P. Ruanpanun · H. Laatsch}

Department of Organic and Biomolecular Chemistry, University of Göttingen, Tammannstraße 2, 37077 Göttingen, Germany

e-mail: hlaatsc@gwdg.de

\section{N. Tangchitsomkid}

Department of Agriculture, Nematology Section, Plant

Protection Research and Development Office,

Bangkok 10900, Thailand

e-mail: nuchanart@yahoo.com

\section{S. Lumyong $(\bowtie)$}

Microbiology Division, Department of Biology, Faculty of Science, Chiang Mai University, Chiang Mai 50200, Thailand e-mail: scboi009@chiangmai.ac.th against egg hatch of $M$. incognita was $30 \mu \mathrm{g} / \mathrm{ml}$ and juvenile mortality of $M$. incognita increasing was observed at $120 \mu \mathrm{g} / \mathrm{ml}$. Moreover, at the concentration of $250 \mu \mathrm{g} / \mathrm{ml}$ fervenulin (1) showed killing effect on second-stage nematode juveniles of $M$. incognita up to $100 \%$ after incubation for $96 \mathrm{~h}$. Isocoumarin (2), another bioactive compound produced by Streptomyces sp. CMU-MH021, showed weak nematicidal activity with $M$. incognita.

Keywords Streptomyces sp. CMU-MH021 - Fervenulin · Nematicidal activity $\cdot$ Root-knot nematode
Abbreviations
RKNs Root-knot nematodes
J2 Second-stage nematode juveniles

\section{Introduction}

Plant-parasitic nematodes such as root-knot nematodes (RKNs) or Meloidogyne spp. are microscopic obligate biotrophic pathogens that feed on plant roots. They cause severe damage to a wide variety of crops and lead to significant yield losses of approximately 78 billion dollar worldwide annually (Barker 1998; Caillaud et al. 2008; Sun et al. 2006; Verdejo-Lucas 1999). They are found in all temperate and tropical areas (Caillaud et al. 2008; Trudgill and Block 2001). It has been reported that RKNs spread out in agricultural areas in north, northeastern and central regions of Thailand (Cliff and Hirschmann 1984; Handoo et al. 2005; Ruanpanun et al. 2010).

Biological control is an interesting option to control plant-parasitic nematodes instead of the chemical control 
because it is eco-friendly and has no effect on human health (Dong and Zhang 2006; Sun et al. 2006). Microorganisms are the main tool for managing these pathogens (Dicklow et al. 1993; Saxena 2004).

Actinomycetes are Gram-positive bacteria and have been reported for their nematicidal activity (Sun et al. 2006). Streptomyces spp. are the major group of actinomycetes which show activity against plant-parasitic nematodes by producing nematicidal metabolites (Dicklow et al. 1993; Mishra et al. 1987; Samac and Kindel 2001; Sun et al. 2006). According to El-Nagdi and Youssef (2004), abamectin, a member of the avermectin group obtained from the fermentation products of Streptomyces avermitilis, showed nematicidal activity by the seed soaking treatment of faba beans infested with $M$. incognita. Moreover, it was found that the mortality of $M$. incognita and Rotylenchulus reniformis reached 100 and 97\% respectively, after $24 \mathrm{~h}$ exposure to $21.5 \mu \mathrm{g}$ abamecin $/ \mathrm{ml}$ (Faske and Starr 2006). Furthermore, nematicidal actinomycetes have been implicated in antagonistic ways on other plant pathogens, on fungal diseases (Chung et al. 2005; Liu et al. 2004; Prabavathy et al. 2006; Yu et al. 2008) and bacterial diseases (El-Shanshoury 1994; Liu et al. 1995; Ndonde and Semu 2000). The present study describes the bioassay-guided isolation of a compound responsible for in vitro inhibition of $M$. incognita hatch and juvenile mortality by the culture broth, crude extract and pure compounds [fervenulin (1) and 6,8-dihydroxy-3methylisocoumarin (2)] produced by a nematicidal actinomycete, Streptomyces sp. CMU-MH021 (Ruanpanun et al. 2010). Products or pure compounds from this isolate seem to be a new alternative biological agent to control root-knot nematodes in the future.

\section{Materials and methods}

Nematicidal actinomycete isolate

Streptomyces sp. CMU-MH021, a nematicidal actinomycete, was isolated from plant-parasitic nematode infested rhizosphere soils in Thailand (Ruanpanun et al. 2010). A stock culture of the strain was maintained on HickeyTresner (HT) slant agar and kept in 20\% (v/v) glycerol suspension at $-20^{\circ} \mathrm{C}$.

DNA extraction, amplification and sequencing of $16 \mathrm{~S}$ rDNA

The Streptomyces sp. CMU-MH021 was grown for 4 days at $28^{\circ} \mathrm{C}$ with agitation in $250 \mathrm{ml}$ Erlenmeyer flasks containing $50 \mathrm{ml}$ of $\mathrm{YM}$ broth. Biomass was harvested by centrifugation at $11,000 \mathrm{rev} / \mathrm{min}$ and washed twice with sterile distilled water. About $250 \mathrm{mg}$ of mycelia was used for DNA extraction by using Wizard $^{\circledR}$ genomic DNA purification kit (Promega, WI).

The 16S rDNA was amplified by using the PCR method with $T a q$ DNA polymerase and primers $27 \mathrm{f}\left(5^{\prime}\right.$ AGA GTT TGA TCM TGG CTC AG $3^{\prime}$ ) and 1525r ( $5^{\prime}$ AAG GAG GTG WTC CAR 3'; Khamna et al. 2009). The condition for thermal cycling were as following: denaturation of target DNA at $95^{\circ} \mathrm{C}$ for 5 min followed by 30 cycles at $95^{\circ} \mathrm{C}$ for $1 \mathrm{~min}$, primer annealing at $55^{\circ} \mathrm{C}$ for $1 \mathrm{~min}$ and primer extension at $72^{\circ} \mathrm{C}$ for $1 \mathrm{~min}$. At the end of the cycling, the reaction mixture was kept at $72^{\circ} \mathrm{C}$ for $10 \mathrm{~min}$ and cooled to $4^{\circ} \mathrm{C}$. Negative controls (no added DNA) were included in all reaction sets. PCR amplifications were detected by $1 \%(\mathrm{w} / \mathrm{v})$ agarose gel electrophoresis and visualized by ultraviolet (UV) fluorescence after stained with ethidium bromide. The PCR products were purified by using a QIA Quick Gel Extraction kit (Qiagen, Valencia, CA) and directly sequenced by Macrogen Inc., (Seoul, South Korea). The sequencing primers including primer 27f, primer MG3f (5' CTA CGG GRS GCA GCA G $\left.3^{\prime}\right)$ and primer MG5f ( $5^{\prime}$ AAA CTC AAA GGA ATT GAC GG 3') were used for this purpose (Nimnoi et al. 2010). The obtained sequence was compared using BLAST program for similarity with the reference species of bacteria contained in GenBank, which is available at http://www.ncbinlm-nih.gov/.

\section{Media optimization and production}

Five different media including Bennett's broth (beef extract $0.1 \%$, glucose $1 \%$, NZ amine type A $0.2 \%$, yeast extract 0.4\%; pH 7.3) (Gerber 1973), Emerson's broth (soluble starch $1.5 \%$, yeast extract $0.4 \%, \mathrm{MgSO}_{4} 0.5 \%$, $\mathrm{Na}_{2} \mathrm{HPO}_{4}$ 0.1\%; pH 6.8) (Weiss 1975), F-4 (glycerol 4.0\% soybean meal $2.5 \%$, yeast extract $0.5 \%, \mathrm{CaCO}_{3} 0.2 \%$, $\mathrm{NaCl}$ 0.05\%) (Cheeptham et al. 1999), Basal medium (soluble starch $3.3 \%$, defatted peanut powder $1.7 \%, \mathrm{NaCl}$ $0.2 \%,\left(\mathrm{NH}_{4}\right)_{2} \mathrm{SO}_{4} 0.23 \%$ ) and $\mathrm{MB}$ medium (soluble starch $5.3 \%$, soybean meal $1.0 \%,\left(\mathrm{NH}_{4}\right)_{2} \mathrm{SO}_{4} 0.62 \%, \mathrm{NaCl}$ $0.58 \%$ ) (Yu et al. 2008) were preliminary used to determine the optimal nutrient for the growth and production of bioactive compounds.

Inoculum preparation and liquid culture

The strain was sub-cultured on starch-casein agar (SCA) plates for 5 days at $28^{\circ} \mathrm{C}$. Three small pieces $(5 \mathrm{~mm}$ diam.) of the agar culture were then used to inoculate into oneL Erlenmeyer flasks each containing $300 \mathrm{ml}$ of MB medium composed of starch $5.33 \%$, soybean meal $0.94 \%$, $\left(\mathrm{NH}_{4}\right)_{2} \mathrm{SO}_{4} 0.62 \%, \mathrm{NaCl} 0.58 \%$ and $\mathrm{pH}$ was adjusted to 7.0 
(Liu et al. 2004; Yu et al. 2008). All flasks were incubated on a rotator shaker at $130 \mathrm{rev} / \mathrm{min}$ at $28^{\circ} \mathrm{C}$ for 7 days.

Preparation of crude extract

The culture broth was mixed with Celite $(\sim 1 \mathrm{~kg})$ and filtrated under pressure. The mycelium was extracted three times with ethyl acetate and twice with acetone. The liquid phase was adsorbed on an Amberlite XAD-16 column and the organic compounds were eluted with methanol. The methanol was removed by evaporation $i$. vac., the aqueous residue was then extracted with ethyl acetate. The organic phase was also evaporated to dryness. The resulting crude extract ( $5 \mathrm{~g}$ ) having nematicidal activity was then subjected to separation on silica gel and Sephadex LH-20.

Purification of active compound

Crude extract (5 g) of Streptomyces sp. CMU-MH021 was chromatographed on silica gel (column $50 \times 4 \mathrm{~cm}$ ) with a stepwise $\mathrm{CH}_{2} \mathrm{Cl}_{2} / \mathrm{MeOH}$ gradient of increasing polarity. Fractions were monitored by thin-layer chromatography (TLC, silica gel, $\mathrm{CH}_{2} \mathrm{Cl}_{2} / \mathrm{MeOH} 19: 1$, spraying with anisaldehyde/sulfuric acid reagent and warming). Similar fractions were combined and tested with eggs and secondstage nematode juveniles ( $\mathrm{J} 2)$ of $M$. incognita.

The active fraction ( $1 \mathrm{~g}$ ) was further purified twice on Sephadex LH-20 (columns $40 \times 3 \mathrm{~cm}, \mathrm{MeOH}$ and then $60 \times$ $1 \mathrm{~cm}, \mathrm{CH}_{2} \mathrm{Cl}_{2} / \mathrm{MeOH} 1: 1,0.5 \mathrm{ml} / \mathrm{min}$ ) (Fig. 1). The pure compounds were analyzed by ${ }^{1} \mathrm{H}$ and ${ }^{13} \mathrm{C}$ nuclear magnetic resonance spectroscopy (NMR) and ESI mass spectrometry.

Nematicidal activity

Culture broth, crude extract, 12 fractions, and pure compounds (fervenulin and 6,8-dihydroxy-3-methylisocoumarin from fraction 5) from the nematicidal actinomycete isolate, Streptomyces sp. CMU-MH021 were tested on eggs and second-stage nematode juveniles (J2) of $M$. incognita. The samples were dissolved in dimethyl sulfoxide (DMSO) before adding water (final concentration: 0.5\% DMSO) while the culture broth was tested directly. The concentration of samples was adjusted to $250 \mu \mathrm{g} / \mathrm{ml}$. Active samples were further tested at 120, 60 and $30 \mu \mathrm{g} / \mathrm{ml}$ (Nitao et al. 2002).

Meloidogyne incognita was cultured on chili (Capsicum frutescens L.) in the green house for 45 days, and its eggs were collected from the roots following the procedures described by Sun et al. (2006) with some modifications. Eggs were surface-disinfected with $1 \%$ sodium hypochlorite $(\mathrm{NaOCl})$ and washed three times with sterile distilled water to remove residual $\mathrm{NaOCl}$. They were incubated at room temperature $\left(25 \pm 3^{\circ} \mathrm{C}\right)$ for $48 \mathrm{~h}$ for the newly hatched $\mathrm{J} 2$. A $50 \mu \mathrm{l} \mathrm{J} 2$ suspension (150-200 J2/50 $\mu \mathrm{l}$ ) was transferred into each well of a 24 -well tissue culture plate containing $1 \mathrm{ml}$ of sample solution. As negative control, $0.5 \%$ DMSO in water was used. The plate was incubated at room temperature $\left(25 \pm 3^{\circ} \mathrm{C}\right)$ for $96 \mathrm{~h}$ and daily examined for dead J2. Three replicates were done for each sample. Living and dead juveniles were counted under the microscope; mortality was calculated according to the formula: juvenile mortality $=100 \times$ dead juveniles/total juveniles (Sun et al. 2006). The immobile, malformed, or motionless juveniles when probed with a fine needle were considered to be dead.

Hatching inhibition analysis

All chemical substances were prepared as previously described. Eggs from root-knot nematode cultured in a green house on chili were surface-disinfected with $1 \%$ sodium hypochlorite $(\mathrm{NaOCl})$ and washed three times with sterile distilled water to remove residual $\mathrm{NaOCl}$. A $50 \mu \mathrm{l}$ egg suspension (150-200 eggs/50 $\mu \mathrm{l}$ ) was pipetted into each well of a 24-well tissue culture plate containing $1 \mathrm{ml}$ of test solution. The plate was incubated at room temperature $\left(25 \pm 3^{\circ} \mathrm{C}\right)$ for 7 days and daily examined for egg hatch rate. Three replicates were done for each sample. Percentage of egg hatch was determined by counting all eggs and juveniles under the microscope and calculated according to the formula: percentage of egg hatch = $100 \times$ juveniles/(eggs + juveniles) (Sun et al. 2006).

\section{Toxicity assay}

The nematode effective compound fervenulin (1) was tested for brine shrimp (Artemia salina) toxicity. Fervenulin (1) was dissolved in DMSO at a concentration of $1 \mathrm{mg} / \mathrm{ml}$ for this experiment (Jumpathong et al. 2010; McLaughlin et al. 1998).

Artemia salina eggs were suspended in artificial seawater and kept in a separation funnel under aeration for 3 days for hatching. A $990 \mu \mathrm{l}$ larvae suspension $(\sim 50$ larvae) was pipetted into each well of a 24-well tissue culture plate. Ten $\mu$ l of the DMSO solution was added into each well, DMSO was added as control. The plate was incubated at room temperature $\left(25 \pm 3^{\circ} \mathrm{C}\right)$ for $24 \mathrm{~h}$. The mortality of $A$. salina was determined by counting living and dead larvae and calculated according to \% mortality $=100 \times$ dead larvae/total number of larvae.

Statistical analysis

All experimental data were analyzed by the statistic package SPSS (program version 16.0 (2007), SPSS Inc., 
Fig. 1 Work-up schema for the purification of active molecule of the nematicidal actinomycete, Streptomyces sp. CMU-MH021

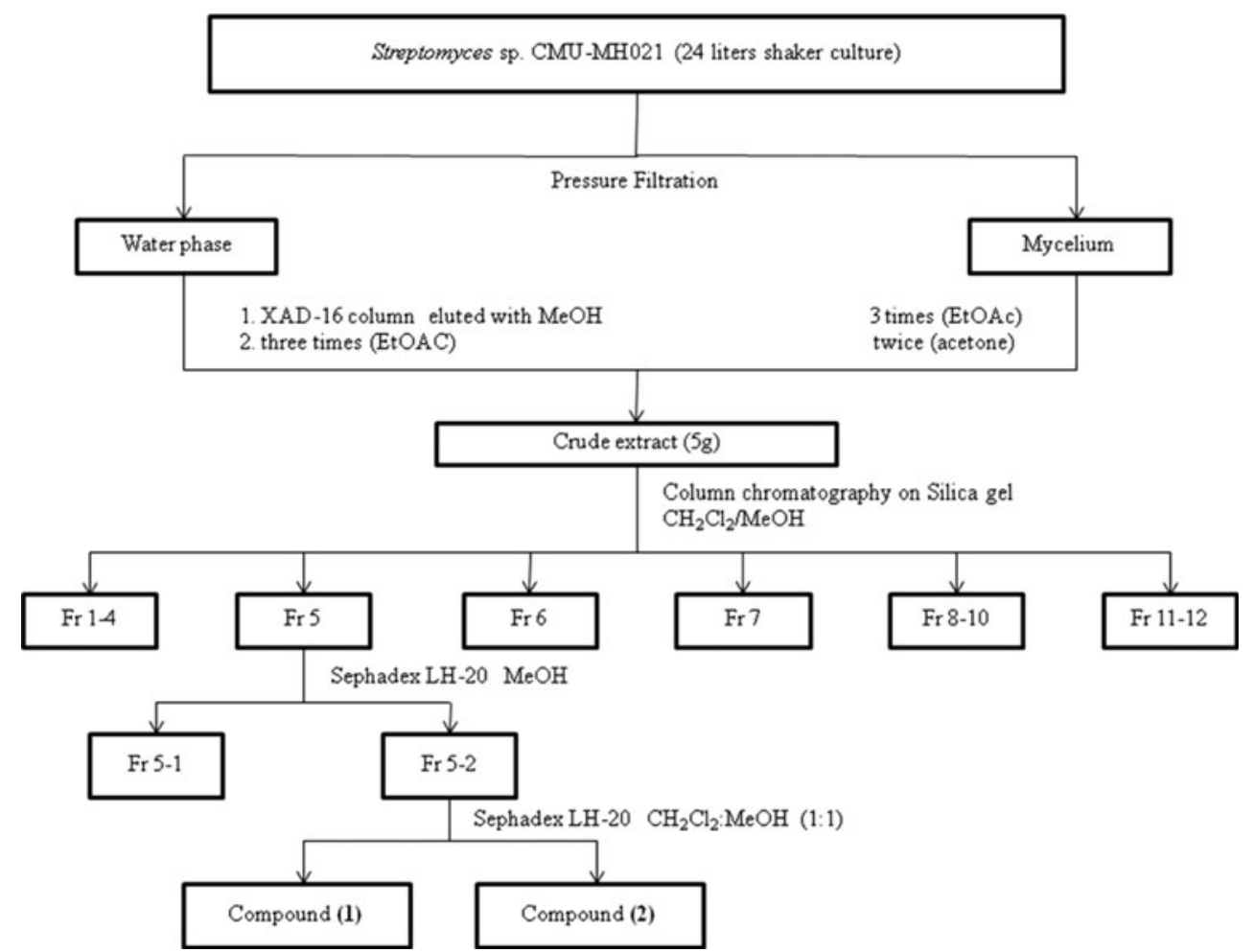

Chicago, IL). The data were subjected to variance analysis (ANOVA) using Duncan's test $(P<0.05)$.

\section{Results}

Nematicidal Actinomycete, Streptomyces sp. CMUMH021

A nematicidal actinomycete strain CMU-MH021 was previously isolated from plant-parasitic nematode infested rhizosphere soil at Mae Hae village, Chiang Mai province, Thailand. The strain exhibited nematicidal activity against M. incognita and was chemotaxonomically classified as Streptomyces sp. (Ruanpanun et al. 2010). The 16S rDNA gene sequence (GenBank, accession number HM101167) of this strain was similar to Streptomyces roseoverticillatus ( $99 \%$ identity).

\section{Media optimization}

Different phenotypes of Streptomyces sp. CMU-MH021 were observed on different media including Bennett's broth, Emerson's broth, F-4 medium, Basal medium and MB medium. The isolate grew on all media, and culture broths and crude extracts showed significant effects $(P<0.05)$ on egg hatch and $\mathrm{J} 2$ mortality when compared with the control. The culture broth and crude extract from fermentation in MB medium showed the highest inhibition of egg hatch and the highest toxicity for $\mathrm{J} 2$ of $M$. incognita. The culture filtrate decreased percentage of egg hatch to $10.39 \pm 1.3 \%$ after 7 days and increased percentage of $\mathrm{J} 2$ mortality to $100 \%$ after $96 \mathrm{~h}$; the crude extract decreased percentage of egg hatch to $32.25 \pm 7.3 \%$ and also increased percentage of $\mathrm{J} 2$ mortality to $100 \%$ (Table 1). Thus MB medium was selected to culture the isolate for this study.

Nematicidal and hatching inhibition assays

Culture broth (MB medium) and crude extract $(250 \mu \mathrm{g} / \mathrm{ml})$ from Streptomyces sp. CMU-MH021 significantly reduced root-knot nematode hatch and increased $\mathrm{J} 2$ mortality in vitro. The crude extract was separated by fractionation on silica gel. Twelve fractions were tested on eggs and J2 of M. incognita. Fraction 5 decreased percentage of egg hatch to $14.6 \pm 4.0 \%$ after incubation for 7 days and increased percentage of $\mathrm{J} 2$ mortality to $69.2 \pm 2.5 \%$ after incubation for $96 \mathrm{~h}$, in contrast to the control with $85.8 \pm 4.6$ and $3.9 \pm 0.9 \%$, respectively (Fig. 2). From this fraction, two pure compounds were isolated by column chromatography on Sephadex LH-20. The first compound 1 appeared on thin-layer chromatography as a yellow, UV absorbing spot, whose color did not change with anisaldehyde/sulfuric acid; it yielded a yellow crystalline solid. EI MS indicated a molecular ion at $\mathrm{m} / \mathrm{z} .193$, which was confirmed by (+)ESI MS with pseudomolecular ions at $194\left([\mathrm{M}+\mathrm{H}]^{+}\right)$and $216\left([\mathrm{M}+\mathrm{Na}]^{+}\right)$. ESI HRMS afforded the formula 
Table 1 Nematicidal activities of crude extract at $250 \mu \mathrm{g} / \mathrm{ml}$ (A) and culture broth (B) from Streptomyces sp. CMU-MH021

\begin{tabular}{|c|c|c|c|c|c|}
\hline \multirow[t]{2}{*}{ Sample } & \multirow[t]{2}{*}{ Egg hatch rate $(\%)(7 \text { days })^{a}$} & \multicolumn{4}{|c|}{ Juvenile mortality rate $(\%)$} \\
\hline & & $24 \mathrm{~h}^{*}$ & $48 \mathrm{~h}^{*}$ & $72 \mathrm{~h}^{*}$ & $96 \mathrm{~h}^{\mathrm{a}}$ \\
\hline Bennett's broth (A) & $60.83 \pm 4.8 \mathrm{def}^{* *}$ & 15 & 35 & 40 & $67.63 \pm 2.4 \mathrm{c}$ \\
\hline Bennett's broth (B) & $69.13 \pm 8.3 \mathrm{fg}$ & 20 & 35 & 40 & $69.00 \pm 6.5 c$ \\
\hline Emerson's broth (A) & $64.06 \pm 7.7 \mathrm{ef}$ & 10 & 30 & 50 & $59.53 \pm 3.2 \mathrm{~d}$ \\
\hline Emerson's broth (B) & $49.19 \pm 13.0 \mathrm{~cd}$ & 25 & 30 & 45 & $71.13 \pm 5.4 \mathrm{bc}$ \\
\hline AHU-5 (A) & $53.62 \pm 12.6 \mathrm{cde}$ & 20 & 30 & 50 & $57.47 \pm 4.7 \mathrm{~d}$ \\
\hline AHU-5 (B) & $71.66 \pm 5.8 \mathrm{fg}$ & 30 & 35 & 45 & $66.27 \pm 6.1 \mathrm{c}$ \\
\hline Basal medium (A) & $30.43 \pm 5.0 \mathrm{~b}$ & 20 & 35 & 45 & $57.93 \pm 2.0 \mathrm{~d}$ \\
\hline Basal medium (B) & $43.12 \pm 3.8 b c$ & 20 & 30 & 50 & $77.17 \pm 3.9 b$ \\
\hline Modified basal medium (A) & $10.39 \pm 1.3 \mathrm{a}$ & 30 & 40 & 50 & $100 \mathrm{a}$ \\
\hline Modified basal medium (B) & $32.25 \pm 7.3 b$ & 40 & 60 & 100 & $100 \mathrm{a}$ \\
\hline Control $\left(\mathrm{H}_{2} \mathrm{O}\right)$ & $86.46 \pm 7.7 \mathrm{~h}$ & 0 & 0 & 0 & $3.93 \pm 0.8 \mathrm{e}$ \\
\hline Control (1\% DMSO) & $82.69 \pm 9.9 \mathrm{gh}$ & 0 & 0 & 0 & $5.57 \pm 0.8 \mathrm{e}$ \\
\hline
\end{tabular}

a Average \pm standard error from three replicates

* Observed mortality $(\%)$

** Value with the same letter are not significantly different $(P<0.05)$ according to Duncan's test

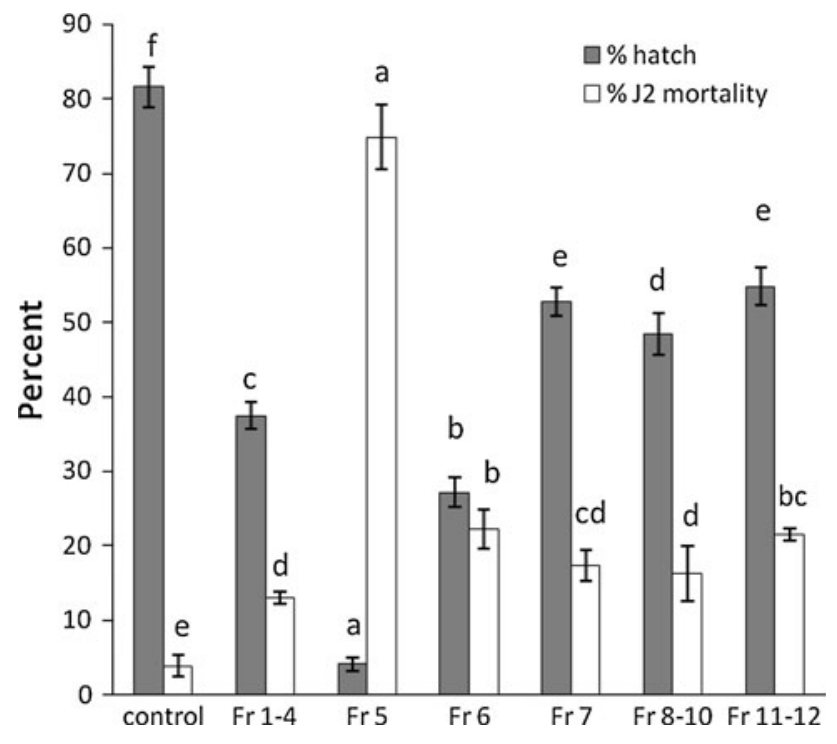

Fig. 2 The in vitro egg hatch after 7 days and juvenile mortality after $96 \mathrm{~h}$ of Meloidogyne incognita in respond to solutions of compounds in medium pressure liquid chromatography fraction of Streptomyces sp. CMU-MH021 at a concentration of $250 \mu \mathrm{g} / \mathrm{ml}$. The representation's bars are standard deviations. The same letter above bars within a graph indicates no significant difference according to the Duncan's test at $P<0.05$

$\mathrm{C}_{7} \mathrm{H}_{7} \mathrm{~N}_{5} \mathrm{O}_{2} \quad$ (exp. 216.04921, calcd. 216.04920 for $\left.[\mathrm{M}+\mathrm{Na}]^{+}\right)$. The ${ }^{1} \mathrm{H}$ NMR spectrum of this compound $\left(\mathrm{CDCl}_{3}, 600 \mathrm{MHz}\right)$ showed singlets at $\delta 9.80(1 \mathrm{H}), 3.88$ $(3 \mathrm{H})$, and $3.54(3 \mathrm{H})$, the ${ }^{13} \mathrm{C}$ NMR spectrum (MeOD, $125 \mathrm{MHz}$ ) gave signals at $\delta 161.6,154.6,152.9,151.2$, 133.9, 29.8, and 29.4. A search in AntiBase (Laatsch 2010) with these data delivered fervenulin (1, Fig. 3); the<smiles>Cn1c(=O)c2ncnnc2n(C)c1=O</smiles>

Fig. 3 Chemical structure of fervenulin (6,8-Dimethylpyrimido(5,4e)-1,2,4-triazine-5,7 $(6 \mathrm{H}, 8 \mathrm{H})$-dione $)$<smiles>Cc1cc2cc(O)cc(O)c2c(=O)o1</smiles>

Fig. 4 Chemical structure of isocoumarin (6,8-Dihydroxy-3methylisocoumarin)

isomeric toxoflavin was clearly excluded by the NMR data (Esipov et al. 1973).

The second compound 2 appeared on thin-layer chromatography as a UV absorbing colorless spot, which turned yellow with anisaldehyde/sulfuric acid. A search with the NMR values [ ${ }^{1} \mathrm{H}$ (DMSO- $d 6,600 \mathrm{MHz}$ ): $\delta 6.42,6.27,6.24$ (3 s, 1H each), 2.19 (s, 3H); ${ }^{13} \mathrm{C}(\mathrm{MeOD}, 125 \mathrm{MHz}): \delta$ 167.7, 167.3, 164.7, 155.4, 141.3, 105.4, 103.4, 102.4, 99.4, 19.2] and the (+)-ESI MS data $\left(\mathrm{m} / z 215\right.$ for $\left.[\mathrm{M}+\mathrm{Na}]^{+}\right)$in 


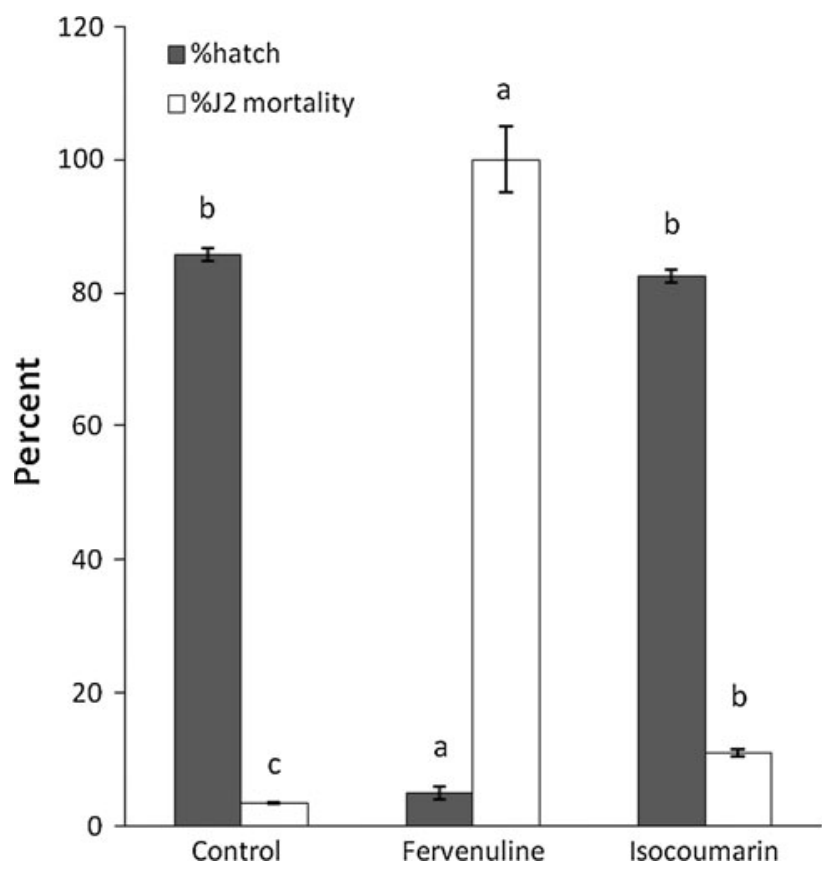

Fig. 5 The in vitro egg hatch after 7 days and juvenile mortality after $96 \mathrm{~h}$ of Meloidogyne incognita in respond to fervenulin and isocoumarin, the compound from fraction 5 of Streptomyces sp. CMU-MH021 at a concentration of $250 \mu \mathrm{g} / \mathrm{ml}$. The representation's bars are standard deviations. The same letter above bars within a graph indicates no significant difference according to the Duncan's test at $P<0.05$
AntiBase (Laatsch 2010) delivered 6,8-dihydroxy-3methylisocoumarin (2, Fig. 4) (Ayer et al. 1986).

Fervenulin (1) decreased percentage of egg hatch $5.0 \pm 2.0 \%$ after incubation for 7 days and increased percentage of $\mathrm{J} 2$ mortality to $100.0 \pm 0.0 \%$ after incubation for $96 \mathrm{~h}$ at concentration of $250 \mu \mathrm{g} / \mathrm{ml}$ (Figs. 5, 6), which significantly $(P<0.05)$ differed from the control. A significant effect on hatch compared with the control was also found after 7 days at concentrations of 120,60 and $30 \mu \mathrm{g} / \mathrm{ml}$ (Fig. 7a). Significant effects were found on $\mathrm{J} 2$ mortality as well after $96 \mathrm{~h}$ at a concentration of $120 \mu \mathrm{g} / \mathrm{ml}$, but not at 60 or $30 \mu \mathrm{g} / \mathrm{ml}$ (Fig. 7b). The isocoumarin 2 showed weak effect on $\mathrm{J} 2$ mortality but no effect on egg hatching inhibition on $M$. incognita at a concentration of $250 \mu \mathrm{g} / \mathrm{ml}$.

\section{Toxicity assay}

The nematicidal compound, fervenulin (1), showed no toxic effect to brine shrimps (Artemia salina) at a concentration of $10 \mu \mathrm{g} / \mathrm{ml}$ after incubation for $24 \mathrm{~h}$.

\section{Discussion}

Natural products from actinomycetes, especially Streptomyces spp., are a very promising source of new chemicals
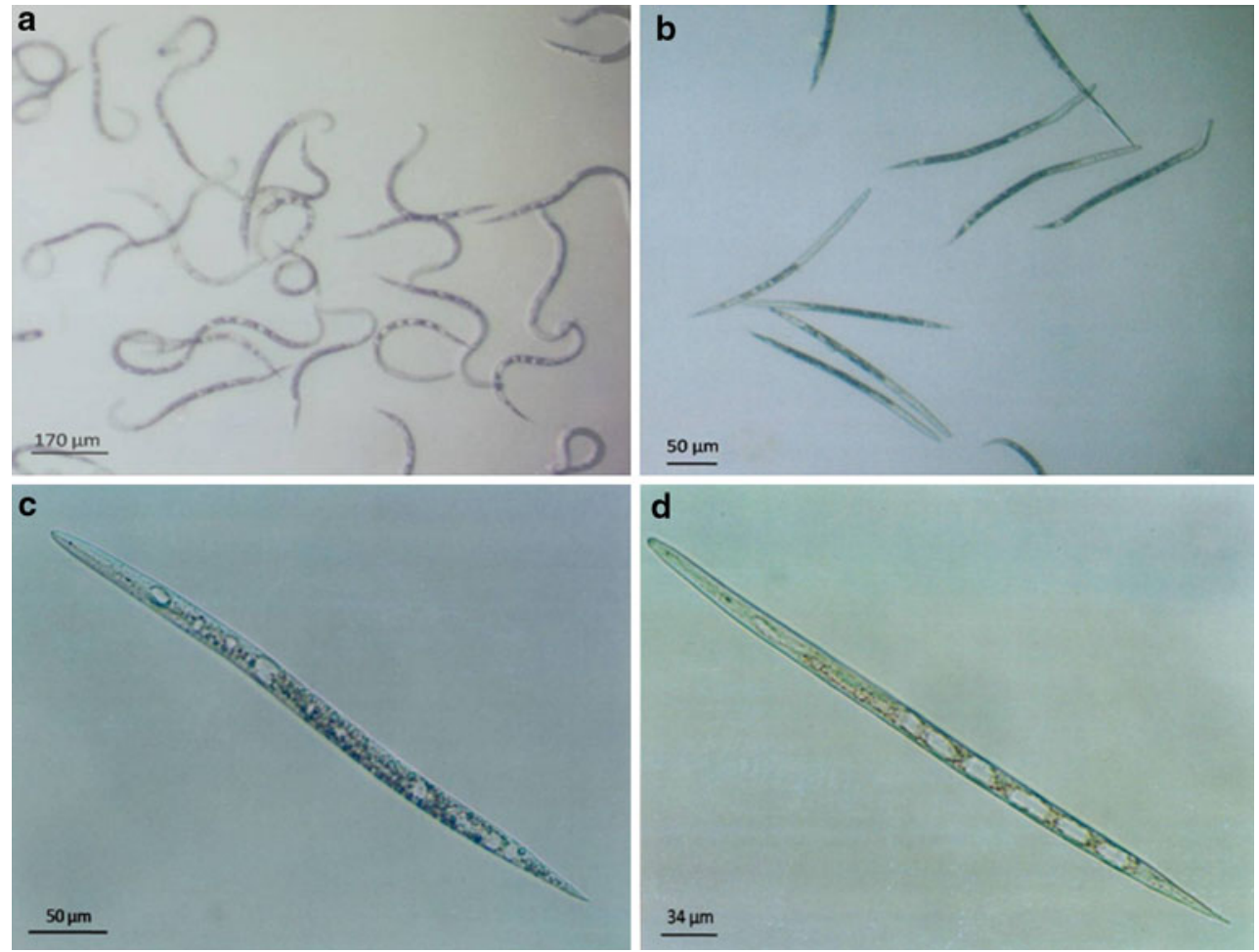

Fig. 6 Meloidogyne incognita 2nd-stage juvenile after treatment with fervenulin isolated from Streptomyces sp. CMU-MH021 a Non-treated; b Treated with fervenulin for $96 \mathrm{~h}$; c Dead J2 of M. incognita caused by fervenulin; d Dead J2 of M. incognita caused by lacking nutrient 
Fig. 7 Percentage of egg hatch (a) and $\mathrm{J} 2$ mortality (b) of $M$. incognita after 7 days and $96 \mathrm{~h}$, respectively in vitro in three concentration of fervenulin isolated from Strptomyces sp. CMU-MH021 (mean \pm SE, $n=3 ; 150-200$ eggs or $\mathrm{J} 2$ per replication)

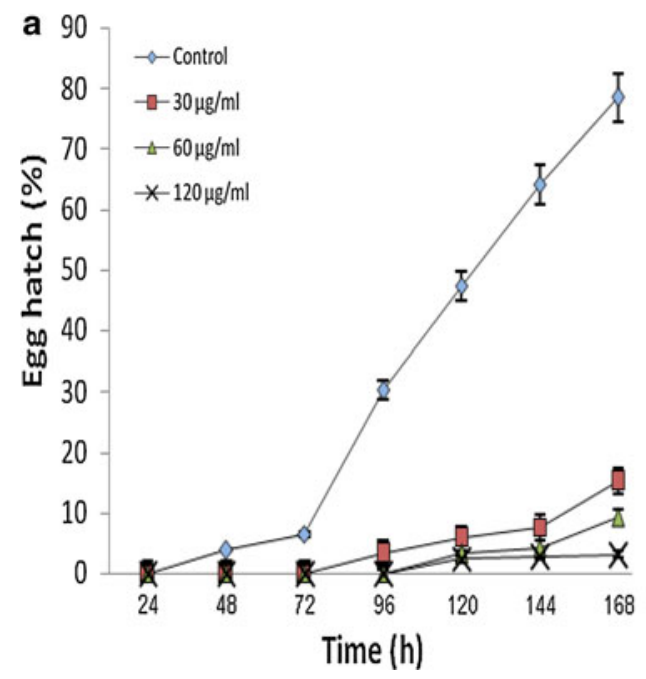

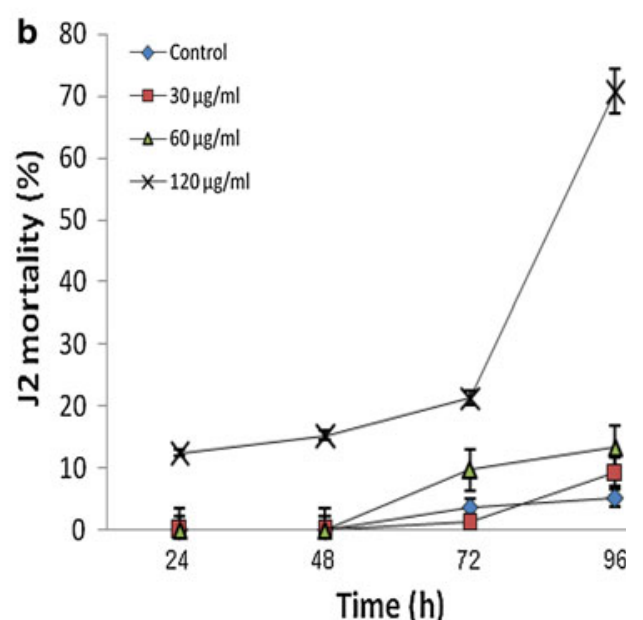

to manage plant-parasitic nematodes (Chubachi et al. 1999; Dong and Zhang 2006; El-Nagdi and Youssef 2004; McGovern et al. 2002; Samac and Kindel 2001;). Fervenulin (1), known also as planomycin, is a yellow crystalline solid, which was previously isolated from $S$. fervens and S. rubrireticuli (Liao et al. 1965). Fervenulin (1) has a broad range of biological activities, e.g., in vitro antibacterial, antifungal, antiparasitic, and antitumor properties (DeBoer et al. 1960). In this study, it was found that it decreased percentage of egg hatch and increased percentage of $\mathrm{J} 2$ mortality of $M$. incognita significantly when compared with the control.

The second compound from Streptomyces sp. CMUMH021 was identified as 6,8-dihydroxy-3-methylisocoumarin (2), previously isolated from the fungus Ceratocystis minor (Kumagai et al. 1990), from Streptomyces sp. GT061089 (Tang et al. 2000) and Streptomyces sp. TN97 (Mehdi et al. 2006). This compound was reported to strongly inhibit horse radish peroxidase, to show antitumor activity (McGraw and Hemingway 1977), antiviral (Tang et al. 2000), antimicrobial properties (Mehdi et al. 2006); it had weak nematocidal activity (Fig. 5) in our experiments, although it significantly increase $\mathrm{J} 2$ mortality.

Although the two compounds from Streptomyces sp. CMU-MH021 have already been described from other microorganism and have had their biological activities studied, this is the first report demonstrating that fervenulin (1) has nematicidal activity and inhibits egg hatch and J2 mortality of $M$. incognita. In contrast, the antimicrobial isocoumarin $\mathbf{2}$ was less active against nematodes in our tests.

The producing strain Streptomyces sp. CMU-MH021 was identified by $16 \mathrm{~S}$ rDNA analysis as belonging to Streptomyces roseoverticillatus (99\% identity). MB medium was best suited for strain growth and antagonistic substance production. Scale-up and modification for this strain should be further developed to control root-knot nematode in actual agricultural application.

Acknowledgments This research was supported by The Royal Golden Jubilee Ph. D. Program (PHD/0064/2549). The Graduate School, Chiang Mai University and The Commission of Higher Education for Target Research Initiation Program are thankfully acknowledged.

\section{References}

Ayer WA, Browne LM, Feng MC, Orszanska H, Saeedi-Ghomi H (1986) Some metabolites of Ceratocystis species associated with mountain pine beetle infected lodgepole pine. Can J Chem 65:765-769

Barker KR (1998) Introduction and synopsis of advancements in nematology. In: Barker KR, Pederson GA, Windham GL (eds) Plant and Nematode interactions. Am. Soc. of Agronomy, Inc., Crop Sci. Am. Inc., and Soil Sci. Soc. Am. In., Madison, WI, pp 1-20

Caillaud MC, Dubreuil G, Quentin M, Perfus-Barbeoch L, Lecomte P, Engler JDA, Abad P, Rosso MN, Favery B (2008) Root-knot nematodes manipulate plant cell functions during a compatible interaction. J Plant Physiol 165:104-113

Cheeptham N, Higashiyama T, Phay N, Fukushi E, Matsuura H, Mikawa T, Yokota A, Ichihara A, Tomita F (1999) Studies on an antifungal antibiotic from Ellisiodothis inquinans L1588-A8. Thai J Biotechnol 1:37-45

Chubachi K, Furakawa M, Fukuda S, Takahashi S, Matsumura S, Itagawa H, Shimizu T, Nakagawa A (1999) Control of root-knot nematodes by Streptomyces: screening of root-knot nematodecontrolling actinomycetes and evaluation of their usefulness in a pot test. Nihon Senchu Gakkai Shi 29:42-45

Chung WC, Huang JW, Huang HC (2005) Formulation of a soil biofungicide for control of damping-off of Chinese cabbage (Brassica chinensis) caused by Rhizoctonia solani. Biol Control 32:287-294

Cliff GM, Hirschmann H (1984) Meloidogyne microcephala n. sp. (Meloidogynidae) a root-knot nematode from Thailand. J Nematol 16:183-193

DeBoer C, Dietz A, Evans JS, Michaels RM (1960) Fervenulin, a new crystalline antibiotic. I. Discovery and biological activities. Antibiot Annu 7:220-226 
Dicklow MB, Acosta N, Zuckerman BM (1993) A novel Streptomyces species for controlling plant-parasitic nematodes. J Chem Ecol 19:159-173

Dong LD, Zhang KQ (2006) Microbial control of plant-parasitic nematodes: a five-party interaction. Plant Soil 288:31-45

El-Nagdi WMA, Youssef MMA (2004) Soaking faba bean seed in some bio-agents as prophylactic treatment for controlling Meloidogyne incognita root-knot nematode infection. J Pest Sci 77:75-78

El-Shanshoury AR (1994) Azotobacter chroococcum and Streptomyces atroolivaceus as biocontrol agents of Xanthomonas campestris pv. malvacearum. Acta Microbiol Pol 43:79-87

Esipov SE, Kolosov MN, Saburova LA (1973) The structure of reumycin. J Antibiot 26:537-538

Faske TR, Starr JL (2006) Sensitivity of Meloidogyne incognita and Rotylenchulus reniformis to abamectin. J Nematol 38:240-244

Gerber NN (1973) Minor prodiginine pigments from Actinomadura madurae and Actinomadura pelletieri. J Heterocycl Chem 10:925-929

Handoo ZA, Skantar AM, Carta LA, Erbe EF (2005) Morphological and molecular characterization of a new root-knot nematode, Meloidogyne thailandica n. sp. (Nematoda: Meloidogynidae), parasitizing ginger (Zingiber sp.). J Nematol 37:343-353

Jumpathong J, Abdalla MA, Lumyong S, Laatsch H (2010) Stemphol galactoside, a new stemphol derivative isolation from the tropical endophytic fungus Gaeumannomyces amomi. Nat Prod Commun 5:567-570

Khamna S, Yokota A, Lumyong S (2009) Actinomycetes isolated from medicinal plant rhizosphere soils: diversity and screening of antifungal compounds, indole-3-acetic acid and siderophore production. World J Microbiol Biotechnol 25:649-655

Kumagai H, Masuda T, Ohsono M, Hattori S, Naganawa H, Sawa T, Hamada M, Ishizuka M, Takeuchi T (1990) Cytogenin, a novel antitumor substance. J Antibiot 43:1505-1597

Laatsch H (2010) AntiBase, a Database for rapid dereplication and structure determination of microbial natural products, Wiley$\mathrm{VCH}$, Weinheim, Germany

Liao TK, Baiocchi F, Cheng CC (1965) Synthesis of 1-demethyltoxoflavin (8-demethylfervenulin). J Org Chem 31:900-902

Liu D, Anderson NA, Kinkel LL (1995) Biological control of potato scab in the field with antagonistic Streptomyces scabies. Phytopathology 85:827-831

Liu Q, Wu YH, Yu JC (2004) Purification of active components SN06 in fermentation of Streptomyces rimosus MY02. Acta Phytopath Sinica 31:353-358

McGovern RJ, McSorley R, Bell ML (2002) Reduction of landscape pathogens in Florida by soil solarization. Plant Dis 86:1388-1395

McGraw GW, Hemingway RW (1977) 6, 8-Dihydroxy-3-hydroxymethylisocoumarin, and other phenolic metabolites of Ceratocystis minor. Phytochemistry 16:1315-1316

McLaughlin JL, Rogers LL, Anderson JE (1998) The use of biological assays to evaluate botanicals. Drug Inf J 32:513-524
Mehdi RBA, Sioud S, Fguira LFB, Bejar S, Mellouli L (2006) Purification and structure determination of four bioactive molecules from a newly isolated Streptomyces sp. TN97 strain. Process Biochem 41:1506-1513

Mishra SK, Keller JE, Miller JR, Heisey RM, Nair MG, Putnam AR (1987) Insecticidal and nematicidal properties of microbial metabolites. J Industr Microbiol 2:267-276

Ndonde MJM, Semu E (2000) Preliminary characterization of some Streptomyces species from four Tanzanian soils and their antimicrobial potential against selected plant and animal pathogenic bacteria. World J Microbiol Biotechnol 16:595-599

Nimnoi P, Pongsilp N, Lumyong S (2010) Endophytic actinomycetes isolated from Aquilaria crassna Pierre ex Lec and screening of plant growth promoters production. World J Microbiol Biotechnol 26:193-203

Nitao JK, Meyer SLF, Oliver JE, Schmidt WF, Chitwood DJ (2002) Isolation of flavipin, a fungus compound antagonistic to plantparasitic nematodes. Nematology 4:55-63

Prabavathy VR, Mathivanan N, Murugesan K (2006) Control of blast and sheath blight diseases of rice using antifungal metabolites produced by Streptomyces sp. PM5. Biol Control 39:313-319

Ruanpanun P, Tangchitsomkid N, Hyde KD, Lumyong S (2010) Actinomycetes and fungi isolated from plant-parasitic nematode infested soils: screening of the effective biocontrol potential, indole-3-acetic acid and siderophore production. World $\mathrm{J}$ Microbiol Biotechnol 26:1569-1578

Samac DA, Kindel LL (2001) Suppression of the root-lesion nematode (Pratylenchus penetrans) in alfalfa (Medicago sativa) by Streptomyces spp. Plant Soil 235:35-44

Saxena G (2004) Biocontrol of nematode-borne disease in vegetable crops. In: Mukerji KG (ed) Disease management of fruits and vegetables. Klumer, Netherland, pp 397-450

Sun MH, Gao L, Shi YX, Li BJ, Liu XZ (2006) Fungi and actinomycetes associated with Meloidogyne spp. eggs and females in China and their biocontrol potential. J Invertebr Pathol 93:22-28

Tang YQ, Sattler I, Thiericke R, Grabley S, Feng XZ (2000) Parallel chromatography in natural products chemistry: isolation of new secondary metabolites from Streptomyces sp. In: Proceeding of the fourth international electronic conference on synthetic organic chemistry. http://www.mdpi.org/ecsoc-4.htm

Trudgill DL, Block VC (2001) Apomitic, polyphagous root-knot nematodes: exceptionally successful and damaging biotrophic root pathogens. Annu Rev Phytophatol 39:53-77

Verdejo-Lucas S (1999) Namatodes. In: Albajes R et al (eds) Integrated pest and disease management in Greenhouse crops. Kluwer, Netherlands, pp 61-68

Weiss FA (1975) Maintenance and preservation of cultures. In: Society of American Bacteriologists, manual of microbiological methods. McGraw-Hill Book Co., Inc., New York, pp 99-119

Yu J, Liu Q, Liu Q, Liu X, Sun Q, Yan J, Qi X, Fan S (2008) Effect of liquid culture requirements on antifungal antibiotic production by Streptomyces rimosus MY02. Bioresour Technol 99:2087-2091 